\title{
Investigating Risk Factors in Tender Process Effecting on Contract Implementation Stage in Onshore Oil and Gas Production Facilities Projects
}

\author{
Abdulmageed H. AL-Yafeai ${ }^{1}$, Awad S. Hassan ${ }^{2}$ \& Elsadig E. El hassan ${ }^{3}$ \\ ${ }^{1} \mathrm{PhD}$ Candidate, Civil Engineering Dept., Faculty of Engineering / Sudan University of Science and \\ technology, Sudan \\ ${ }^{2}$ Prof., College of Architecture \& Planning / Sudan University of Science \& technology, Sudan \\ ${ }^{3}$ Ass. Prof., Civil Engineering Dept., Faculty of Engineering / Sudan University of Science \& technology \\ Sudan
}

\begin{abstract}
Risk factors in oil \& gas production facilities projects tender process contribute to project poor quality, delay, cost overrun, claims, disputes, litigation, failurelabandonment, and a bad reputation for the company, in the contract implementation stage, in Arab countries, such as Yemen. This study investigates risk factors in the tender process in onshore oil and gas production facilities projects, via exploratory factor analysis to extract the significant variables based on results of 400 distributed questionnaire in 65 risk factors in nine constructs; and confirmatory factor analysis to ensure, assess, and lor evaluate the explored risk factors. The results show the goodness of fit for the measurement model of extracted risk factors 60 items in nine constructs. The findings help all parties involved in oil \& gas production facilities projects to achieve better attention and allocation of risks in the tender process, as well as good control of risk in the contract implementation stage. Moreover, provide support for practitioners to incorporate risk potential analysis in future projects. Such will also be useful to researchers in the field of oil \& gas projects to have better understand the risk factors in developing countries.
\end{abstract}

Key Words: Exploratory Factor Analysis, Confirmatory Factor Analysis, Risk Factors, Oil \& Gas, Yemen.

\section{INTRODUCTION}

Increasing investment in industrial projects is tantamount to development in any country. Investment in the oil and gas industry is one of the world's largest, most complex, and riskiest investments. The oil and gas industry is divided into two types of projects as per operations: onshore and offshore projects [1]. The onshore oil and gas projects, specifically Oil \& Gas Production Facilities Projects (PFPs), require location of many of the equipment for the production of oil or gas be located at the production site, including separation, treating and processing facilities, infrastructure, pipelines, storage terminals/export facilities equipment and facilities used in support of production operations projects [2]. These projects are divided into a planning phase and an implementation phase [3].

According to [4] , which states that the planning phase, in a typical project of the oil and gas industry, consists of three main phases: identify (feasibility study), select (conceptual design), develop (basic design), as well as execute and operate the project in implementation phase, as shown in figure 1.1. The first three phases before the project execution called Front End Engineering Design (FEED). The main products at the FEED phase are final scope of work, implementation plans, preparing good, realistic estimates for implementation times, performance and cost requirements, contract strategies, tenders obtained from contractors and a chosen contractor. The FEED package is the basis of the tender process for implementation phases in oil and gas projects [4-3].

A decision Gate (DG) as shown in figure 1.2 exists after each pre-execution phase of the project. There are two main purposes for each decision gate: to check if the previous phase is significantly completed and to decide if the project owner still wants to continue with the project. Therefore, decision gate 3 (DG 3) at the end of the FEED phase is the basis for Approval For 
Expenditure (AFE) or Final Investment Decision (FID), meaning official budgeting approval for the execution of the project. As well as, it's the basis of the tender process for implementation phases in oil and gas projects [3-4].

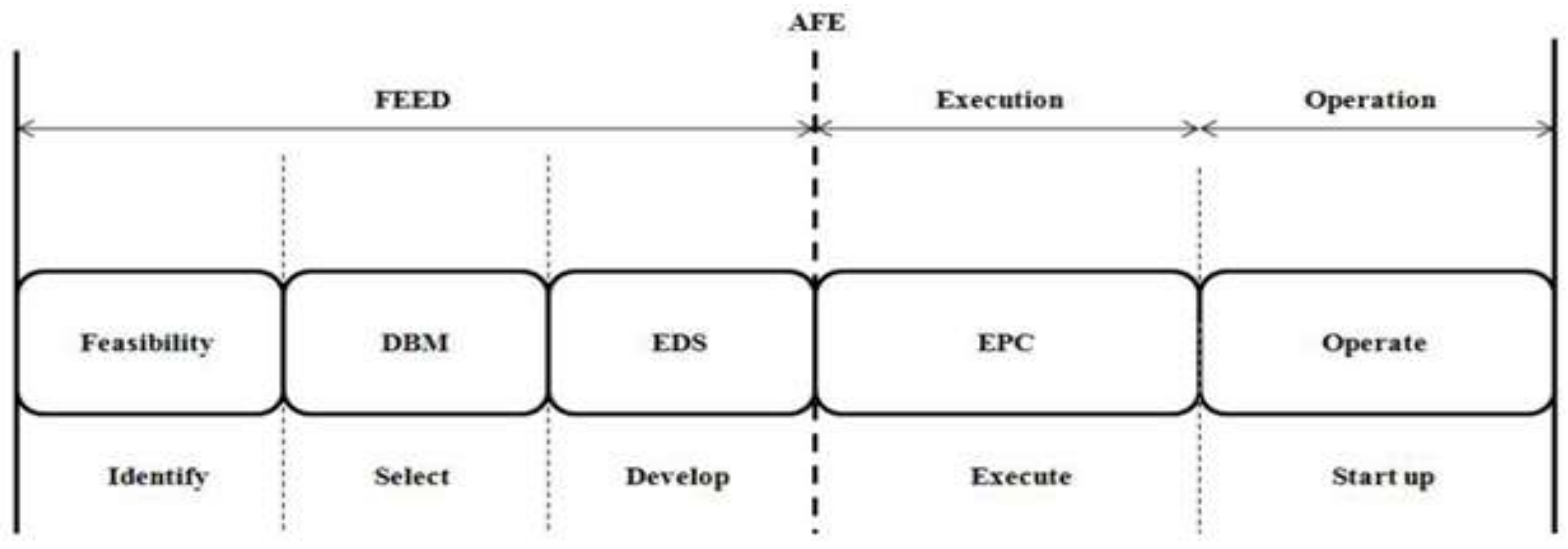

Figure 1.1: The lifecycle of the typical projects in the oil and gas industry (Source : [4]).

In Yemen, oil and gas projects are subject to more risks [5] . It is mentioned in [6-7-8] that the oil and gas PFPs are those projects which are subject to more risks than many other projects. High risk is one of the most distinguishing features of these projects [9-10].

These risks are of high levels because of numerous stockholders, unique nature, complex technology, different size, high investment, and intensified international involvement. The level of risk increases at the beginning of a project [beginning of planning phase], and reaches its highest level [end of planning phase] during the tender process when the project risk is at its peak [11-12].

The tender process is deemed to be the most critical and important throughout the oil and gas PFPs lifecycle [13-14]. This phase shapes the contractual and legislative agreements between the client, consultant team, contractor and other members of the project. The risks increase during this process and reach their peak [13-16-17]. Such risks have an effect on the next phase (implementation phase). A risk may have one or more causes and, if it occurs, may have one or more effects on contracts implementation phase [17-18-19-20].

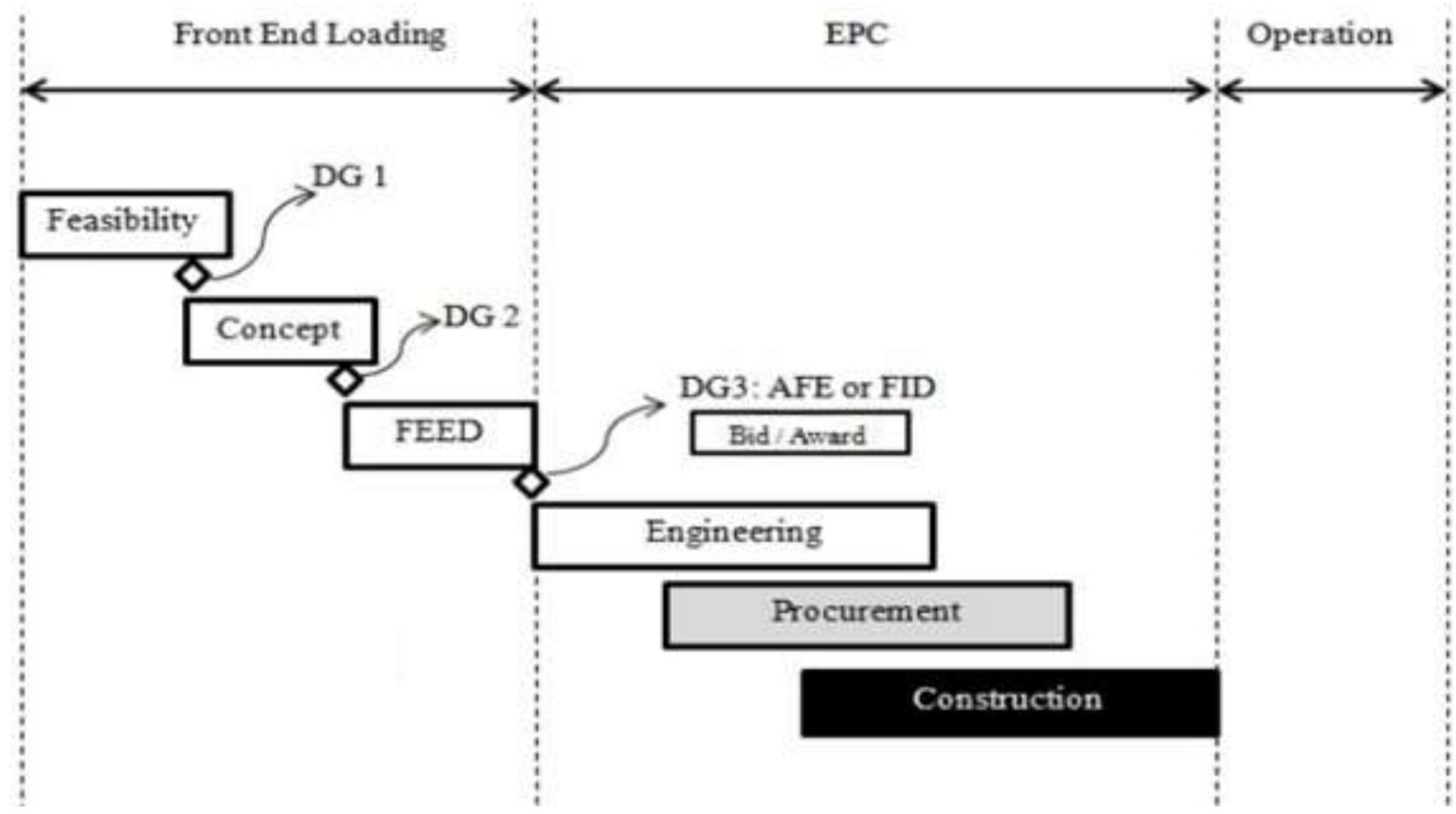

Figure 1.2: Decision gates of the typical projects in the oil and gas industry (Source : [4]).

In this stage, risk factors are a preemptive concept rather than reactive, and as such can, if not properly handled, affect the implementation stage, and lead to lowering and poor quality, cost overrun, time overrun, conflicts, claims, poor project delivery, dispute, negotiation, lawsuit, total desertion, litigation and abandonment [17-18-19-20]. 
The objective of this study is to investigate and identify Risk Factors (RFs), in the tender process, affecting the contract implementation stage in the construction of onshore oil and gas PFPs in Yemen.

\section{LITERATURE REVIEW}

Oil and gas PFPs characterized by increasing complexity, intensified international involvement and different size. Therefore, they are subject to more risks than many other projects. Thus, it is difficult to achieve the project objectives in terms of costs, quality, revenue, and timely completion [6-21].

Risks related to oil and gas PFPs not been thoroughly studied. Just a few studies have focused on risk in the oil and gas sector as shown in table 1.1, as [22] in Vietnam, [23] in Pakistan, [24] in Iran, [25] in U.S.A, [21] in Malaysia, [8] in Sudan, and [26] in Yemen.

Therefore, there is an important need for identifying risks in this part of oil and gas PFPs. This is the first gap, which this study attempts to bridge [7-27].

Table 1.1: Risk factors related to oil and gas projects (Source: Adopted by researcher).

\begin{tabular}{|c|c|c|c|c|c|}
\hline \multirow{2}{*}{$\begin{array}{l}\text { Author } \\
\text { name }\end{array}$} & \multirow[t]{2}{*}{ Year } & \multirow[t]{2}{*}{ Country } & \multirow{2}{*}{$\begin{array}{l}\text { Project } \\
\text { type }\end{array}$} & \multicolumn{2}{|l|}{ Risk Finding } \\
\hline & & & & Categories / Groups & Factors \\
\hline$[22]$ & 2007 & Vietnam & $\begin{array}{l}\text { Oil \& Gas } \\
\text { construction } \\
\text { projects }\end{array}$ & $\begin{array}{l}\text { Divide risks into five categories. Top group of ten risks; } \\
\text { the second group of ten risks; a third group of ten risks; } \\
\text { a fourth group of ten risks and other risks. }\end{array}$ & 59 \\
\hline$[23]$ & 2013 & Pakistan & $\begin{array}{l}\text { Oil \& Gas } \\
\text { Sector EPC } \\
\text { Contracts }\end{array}$ & $\begin{array}{l}\text { Engineering, proposal, project management, } \\
\text { procurement, and contractual, quality, health \& safety } \\
(\mathrm{QH} \& S) \text {, human resource }(\mathrm{HR}) \text {, finance, and audit risk. }\end{array}$ & 162 \\
\hline [24] & 2016 & Iran & $\begin{array}{c}\text { Oil } \\
\text { industry }\end{array}$ & $\begin{array}{l}\text { Scheduling, cost, management weakness, employer, and } \\
\text { contractor. }\end{array}$ & 18 \\
\hline$[25]$ & 2017 & U.S.A & $\begin{array}{l}\text { Oil \& Gas } \\
\text { projects }\end{array}$ & $\begin{array}{l}\text { Cost, schedule, operations, quality, regulatory, (HSE) } \\
\text { risks. }\end{array}$ & - \\
\hline$[21]$ & 2017 & Malaysia & $\begin{array}{l}\text { Oil and Gas } \\
\text { projects }\end{array}$ & $\begin{array}{l}\text { Technical, financial, environmental, design, contractual, } \\
\text { policy, and political risk }\end{array}$ & 29 \\
\hline$[8]$ & 2018 & Sudan & $\begin{array}{l}\text { Oil field } \\
\text { EPCC } \\
\text { construction } \\
\text { projects }\end{array}$ & $\begin{array}{l}\text { Financial and economic, political and legal, design and } \\
\text { specification, safety and health, Acts of God, ecology, } \\
\text { cultural, market inflation, scope change, contractual } \\
\text { failure, time overrun, leadership and organizational } \\
\text { failure, cost overrun, resource failure, quality and } \\
\text { specification failure, and technology change risk. }\end{array}$ & - \\
\hline [26] & 2019 & Yemen & $\begin{array}{l}\text { Oil \& Gas } \\
\text { construction } \\
\text { projects }\end{array}$ & $\begin{array}{l}\text { Client, consultant, tendering \& contract, project } \\
\text { management, local people, security, contractor, } \\
\text { feasibility study \& design, resources and material } \\
\text { supply, economic, political, environmental, force } \\
\text { majeure risk. }\end{array}$ & 51 \\
\hline
\end{tabular}

According to [21], in oil and gas PFPs, the tender process appropriately performed in the early project stage is important for the implementation stage and project success [11-12]. Thus, the tender process in the construction of oil and gas production facilities projects has not received much attention from the researchers, so the researcher tries to focus on this stage of the construction of oil and gas production facilities. This is the second gap that this study attempts to bridge.

The level of risk increases at the beginning of a project and reaches its highest level during the tender process, where the project risk is at its peak [11-12]. The risks related to oil and gas PFPs tender process not been thoroughly studied. There are just very few studies that have focused on risk in this stage, but not in oil and gas projects as shown in table 1.2, such as the study of [12] in Sweden, [28] in China, [29] in Trinidad \& Tobago, and [30] in Netherland. Thus, there is an important need to study the risk factors in the tender process of oil and gas PFPs. This is the third gap that this study attempts to bridge. 
Table 1.2: Risk factors in tender process (Source: Adopted by researcher).

\begin{tabular}{|c|c|c|c|c|c|}
\hline \multirow{2}{*}{$\begin{array}{l}\text { Author } \\
\text { name }\end{array}$} & \multirow[t]{2}{*}{ Year } & \multirow[t]{2}{*}{ Country } & \multirow[t]{2}{*}{ Project type } & \multicolumn{2}{|l|}{ Risk Finding } \\
\hline & & & & Categories / Groups & Factors \\
\hline$[12]$ & 2012 & Sweden & $\begin{array}{l}\text { Infrastructur } \\
\text { al projects }\end{array}$ & $\begin{array}{l}\text { Financial, legal, weather, political, social, third } \\
\text { party, environmental, communications, client, } \\
\text { geographical, geotechnical; subcontractor, } \\
\text { construction, technological, contract, supply, force } \\
\text { majeure, commissioning, completion, injury \& } \\
\text { safety and design risks. }\end{array}$ & - \\
\hline$[28]$ & 2014 & China & $\begin{array}{l}\text { Transportati } \\
\text { on }\end{array}$ & $\begin{array}{l}\text { Economic, nature, political, technological, public } \\
\text { and decision-making and management risks. }\end{array}$ & 16 \\
\hline$[29]$ & 2014 & $\begin{array}{l}\text { Trinidad \& } \\
\text { Tobago }\end{array}$ & $\begin{array}{l}\text { Construction } \\
\text { projects }\end{array}$ & $\begin{array}{l}\text { Price; schedule; quality; health; safety \& welfare } \\
\text { and logistics risks. }\end{array}$ & - \\
\hline$[30]$ & 2015 & Netherland & $\begin{array}{c}\text { Large-scale } \\
\text { projects }\end{array}$ & $\begin{array}{l}\text { Technical, legal, organizational, political, } \\
\text { financial, spatial and social risks. }\end{array}$ & - \\
\hline
\end{tabular}

Risk factors in the tender process may have one or more causes and may, if it occurs, have one or more effects on the contract implementation phase, especially the final project objectives. Therefore, it's very important to investigate and identify the risk factors in this process by the newest tools and techniques, Structural Equation Modeling, or popularly known as (SEM), by Amos program, is one of the newest methods of multivariate data analysis that are specifically developed to overcome the limitations experienced in the Ordinary Least Square (OLS) regressions. In addition, a statistical tool is substantially used for modeling the relationship between several variables. It refers to a combination of factor and regression analysis, and is visualized by a graphical path diagram. It also enables researchers to measure direct and indirect effects, and use several regression equations simultaneously [31-32].

Furthermore, the SEM is more helpful in understanding performance algorithms, because users can visually and systematically recognize complex relationships [33]. As several studies in construction management show, it makes the perfect choice for discovering the interrelationships [33-34]. The SEM is comprised of two types of models: a measurement model (confirmatory factor analysis) and a structural model [31-35].

In this study, Exploratory Factor Analysis (EFA) is used as the basis for the Confirmatory Factor Analysis (CFA) to determine the number of observed variables, as well as measure variables and confirm their reliability and validity by CFA. This is the fourth gap that this study attempts to bridge.

Therefore, this study aims to identify the RFs, in the tender process (early stage), of oil and gas PFPs, affecting the contract implementation stage, (making the project successful) using EFA and CFA.

According to [36], there is a considerable similarity between oil and gas projects and construction projects. Hence, the relevant literature discussing the RFs in the tender process in oil and gas projects and construction projects have been reviewed together, with the prime aim of producing a list of RFs, which are surveyed by oil and gas project teams as shown in table 1.3.

Table1.3: Risk Factor in tender process affecting the contract implementation stage (Source: Adopted by researcher).

\begin{tabular}{|c|c|c|c|}
\hline $\mathrm{Ca}$ & Identifier & Risk Factor & Authors / Source \\
\hline \multirow{5}{*}{ 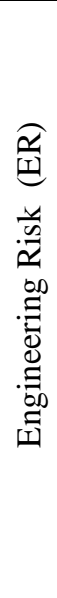 } & ER1 & $\begin{array}{l}\text { Poor project planning in the stages of preliminary } \\
\text { studies FEED (unclear and contain errors). }\end{array}$ & $\begin{array}{l}{[5-7-22-24-37-38-39-40-41-42-43-44-45-} \\
46-48-49-50-51-52-53-54-55-56-57-58- \\
59-60-61-62-63-64-65-66-67-68-69-70- \\
70-71-72-73] .\end{array}$ \\
\hline & ER2 & $\begin{array}{l}\text { Prepared studies, drawings, and specifications based } \\
\text { on previous projects without modification, } \\
\text { according to the nature of the new projects. }\end{array}$ & [61-73-74]. \\
\hline & ER3 & Unclear Project scope. & [7-72-73-74-75-76-77-78-79]. \\
\hline & ER4 & $\begin{array}{l}\text { The engineering drawings are incomplete, contain } \\
\text { mistakes and use non-standard engineering details. }\end{array}$ & $\begin{array}{l}{[5-22-43-44-45-47-50-51-52-53-63-59-} \\
65-66-71-72-73-74-75-80-81-82-83-84- \\
85-86-87-88-89-90-91] .\end{array}$ \\
\hline & ER5 & $\begin{array}{l}\text { The difference between design, construction } \\
\text { standards, and incompatibility between drawing and } \\
\text { method. }\end{array}$ & $\begin{array}{l}{[45-51-52-53-56-58-59-63-65-72-74-75-} \\
84-85-89-92-93] .\end{array}$ \\
\hline
\end{tabular}




\begin{tabular}{|c|c|c|c|}
\hline & ER6 & $\begin{array}{l}\text { Misinterpretation of documents, terms, conditions } \\
\text { and specifications for carrying out the works. And / } \\
\text { or it is unclear, and incomplete. }\end{array}$ & [7-20-61-70-71-72-74-75-84-90-94]. \\
\hline & ER7 & $\begin{array}{l}\text { Obstacles preventing access to the project site and } \\
\text { not visiting the site. }\end{array}$ & [70-71-73-74-76]. \\
\hline & ER8 & Delay in preparation and approval of drawings. & $\begin{array}{l}{[5-22-40-43-44-46-48-51-58-59-64-65-} \\
66-69-71-85-89] .\end{array}$ \\
\hline & ER9 & $\begin{array}{l}\text { Not coordinated design (structural, mechanical, } \\
\text { electrical, etc.). }\end{array}$ & $\begin{array}{l}{[45-47-52-53-56-58-59-63-65-66-73-76-} \\
85-89] .\end{array}$ \\
\hline & ER10 & $\begin{array}{l}\text { Projects need innovative construction method, new } \\
\text { materials, and equipment. }\end{array}$ & $\begin{array}{l}{[24-40-43-44-45-46-47-51-53-55-57-58-} \\
62-65-66-69-71-72-74-75] .\end{array}$ \\
\hline$\overparen{\alpha}$ & PER1 & The quantities are incomplete and wrong. & $\begin{array}{l}\text { [5-20-22-42-43-45-50-53-56-58-59-65- } \\
71-76-83-88-89] .\end{array}$ \\
\hline 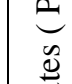 & PER2 & $\begin{array}{l}\text { The cost estimate, and price are incomplete, } \\
\text { inaccurate and contains errors. }\end{array}$ & $\begin{array}{l}{[5-20-22-42-43-45-50-53-55-56-59-61-} \\
65-71-75-76-83-88-89-91] .\end{array}$ \\
\hline 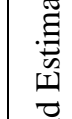 & PER3 & The schedule is not suitable for implementation. & $\begin{array}{l}{[5-22-39-40-42-43-44-45-46-47-49-50-} \\
51-52-53-54-55-56-58-59-63-64-65-66- \\
67-68-71-83-85-88-89-95-96] .\end{array}$ \\
\hline 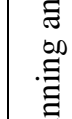 & PER4 & $\begin{array}{l}\text { Inadequate time of the preparation, tender } \\
\text { evaluation and contract awards. }\end{array}$ & $\begin{array}{l}\text { [5-40-42-43-44-45-46-47-49-52-54-56- } \\
58-59-63-64-65-66-67-68-71-83-85-89- \\
96] .\end{array}$ \\
\hline $\begin{array}{l}\frac{\pi}{2} \\
\frac{\pi}{0} \\
\frac{4}{n}\end{array}$ & PER5 & $\begin{array}{l}\text { Inadequate resources, budget estimate and time } \\
\text { schedule planning. }\end{array}$ & $\begin{array}{l}{[5-22-40-42-43-44-45-46-47-49-50-52-} \\
54-58-59-63-64-65-66-67-68-71-83-85- \\
88-89-96-97] .\end{array}$ \\
\hline$\ddot{q}$ & PER6 & $\begin{array}{l}\text { Lack of consistency between bill of quantities, } \\
\text { drawings and specifications. }\end{array}$ & [61-75-76]. \\
\hline & FER1 & The project's cash flow plan is unclear. & $\begin{array}{l}\text { [40-42-43-44-45-46-47-51-52-54-55-56- } \\
59-63-64-65-66-68-83-85-88-89-94-95- \\
96-98-99] .\end{array}$ \\
\hline$\frac{\widehat{x}}{\frac{\pi}{\pi}}$ & FER2 & $\begin{array}{l}\text { Low credibility / Late approval of lenders and } \\
\text { failure to meet their obligations. }\end{array}$ & [70-72-77-79-87-100-101]. \\
\hline$己$ & FER3 & Import, export and customs restrictions. & [ 72-75-79]. \\
\hline$\frac{\vec{n}}{a}$ & FER4 & $\begin{array}{l}\text { Tenderers price and fluctuation in currency } \\
\text { exchange rates. }\end{array}$ & $\begin{array}{l}{[20-71-72-73-76-77-79-78-82-84-86-87-} \\
96-97-101-102-103--104-105] .\end{array}$ \\
\hline छ & FER5 & Insufficient insurance. & [ 5-24-50-71-73-75-80]. \\
\hline 氖 & FER6 & Increased tax and interest rates. & $\begin{array}{l}\text { [71-72-77-79-78-82-84-86-87-97-101- } \\
103-105-106] .\end{array}$ \\
\hline$\frac{\tilde{E}}{\pi}$ & FER7 & $\begin{array}{l}\text { Monopolizing, inflation, labor, and material price } \\
\text { fluctuation. }\end{array}$ & $\begin{array}{l}{[49-65-70-76-79-77-78-79-82-84-86-90-} \\
101-103] .\end{array}$ \\
\hline 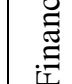 & FER8 & $\begin{array}{l}\text { Financial default and bankruptcy of project } \\
\text { partners. }\end{array}$ & {$[75-76-96-101]$} \\
\hline & FER9 & Financial issues. & $\begin{array}{l}{[5-22-42-44-45-47-50-51-52-54-55-56-} \\
59-66-63-80-85-88-89-101-105] .\end{array}$ \\
\hline & FER10 & $\begin{array}{l}\text { Change in parameters and policies of economic and } \\
\text { tax system. }\end{array}$ & [102]. \\
\hline & MR1 & $\begin{array}{l}\text { Award tender to contractors whose other projects } \\
\text { faltered, and exceeded their technical and financial } \\
\text { potential. }\end{array}$ & [61]. \\
\hline$\stackrel{\alpha}{\Sigma}$ & MR2 & $\begin{array}{l}\text { Lack of effective strategies and systems for } \\
\text { mitigation, protection and defenses of risks. }\end{array}$ & [68]. \\
\hline$\frac{y}{2}$ & MR3 & $\begin{array}{l}\text { Award tender to contractors whose prices are below } \\
\text { the estimated price. }\end{array}$ & [61]. \\
\hline Е & MR4 & $\begin{array}{l}\text { Delays in submission of the project site to the } \\
\text { contractor according to the period agreed upon in } \\
\text { the contract. }\end{array}$ & [40-61-69]. \\
\hline$\sum_{i}^{\tilde{\Xi}}$ & MR5 & $\begin{array}{l}\text { The amount of work to be contracted with the main } \\
\text { contractor and Subcontractor. }\end{array}$ & {$[20-98]$.} \\
\hline & MR6 & $\begin{array}{l}\text { Lack of coordination and communication between } \\
\text { contractors in the tender and contract phase. }\end{array}$ & $\begin{array}{l}{[5-38-40-43-47-49-50-51-54-56-58-62-} \\
63-64-65-66-69-72-74-85-88-89-95-107- \\
108] .\end{array}$ \\
\hline & MR7 & No experience in similar projects. & [5-7-81-91-96-97-106-107]. \\
\hline
\end{tabular}


International Journal of Engineering Research And Advanced Technology, Vol.5, Issue 12, December-2019

\begin{tabular}{|c|c|c|c|}
\hline & MR8 & Internal management problem. & [ 5-22-43-50-80-81-82-83-88-91] \\
\hline & MR9 & Diversity of the decision-making process & $\begin{array}{l}\text { [ 40-42-43-44-45-46-47-50-51-52-54-58- } \\
64-65-66-68-71-85-89] .\end{array}$ \\
\hline & MR10 & $\begin{array}{l}\text { Lack of an effective system for the communication } \\
\text { of risk and / or Unreasonable risk allocation }\end{array}$ & {$[68-95]$} \\
\hline & MR11 & $\begin{array}{l}\text { The approximate prices are not set by the owner } \\
\text { before contract awarding. }\end{array}$ & [61]. \\
\hline \multirow{7}{*}{ 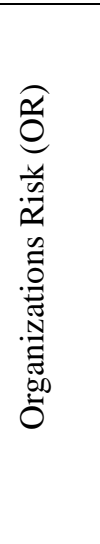 } & OR1 & $\begin{array}{l}\text { Conditions of employment of local and foreign } \\
\text { workers. }\end{array}$ & {$[5-22-88-98]$.} \\
\hline & OR2 & $\begin{array}{l}\text { Lack of conditions and procedures for the selection } \\
\text { and work of persons (job description, job structure, } \\
\text { curriculum vitae). }\end{array}$ & [57], [62], [69], [72]. \\
\hline & OR3 & Organizational deficiencies. & [109]. \\
\hline & OR4 & $\begin{array}{l}\text { Inadequate project organization structure and lack } \\
\text { of organizational commitment. }\end{array}$ & [5-22-43-50-71-88-101]. \\
\hline & OR5 & Inexperienced and unqualified employees. & $\begin{array}{l}\text { [5-24-39-40-42-43-45-46-50-54-56-57- } \\
58-59-61-62-64-65-67-68-69-70-72-73- \\
74-76-81-89-104] .\end{array}$ \\
\hline & OR6 & Unrealistic SWOT analysis. & [102]. \\
\hline & OR7 & Changes in administrative regulations. & [102-109]. \\
\hline \multirow{4}{*}{ 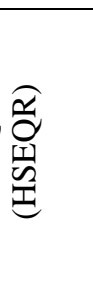 } & HSEQR1 & Poor HSEQ protection procedures and laws. & $\begin{array}{l}{[5-20-22-38-69-72-82-88-91-95-97-106-} \\
108-110] .\end{array}$ \\
\hline & HSEQR2 & $\begin{array}{l}\text { Lack of conditions and procedures of HSEQ at the } \\
\text { site. }\end{array}$ & [5-20-22-76-82-88-106]. \\
\hline & HSEQR3 & $\begin{array}{l}\text { No clear responsibility for who shoulders the risks } \\
\text { during the implementation stage. }\end{array}$ & [38-69-71-72-95-97-108-110] \\
\hline & HSEQR4 & The HSEQ policies and standards are not used. & [ 20-38-69-72-97-102-108-110] \\
\hline \multirow{7}{*}{ 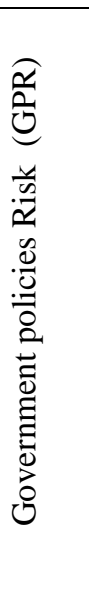 } & GPR1 & $\begin{array}{l}\text { Bureaucracy and long procedure for requirements of } \\
\text { permits / licenses \& approval and failure to grant or } \\
\text { renew approvals. }\end{array}$ & $\begin{array}{l}{[5-20-22-43-50-70-72-73-76-80-81-82-} \\
83-86-88-92-96-101-103-111-112]\end{array}$ \\
\hline & GPR2 & $\begin{array}{l}\text { Relationship with the host government and changes } \\
\text { in law and regulations. }\end{array}$ & $\begin{array}{l}\text { [5-18-22-40-41-43-50-57-62-69-71-72- } \\
73-80-81-82-86-88-93-95-96-100-105- \\
106-111-113] .\end{array}$ \\
\hline & GPR3 & War, revolution, or riots and civil disorder. & [5-22-72-76-77-78-84-86-93-96]. \\
\hline & GPR4 & Embargo and International sanctions. & [75-76-112]. \\
\hline & GPR5 & Expropriation and nationalization. & [72- 92-93-112-123]. \\
\hline & GPR6 & $\begin{array}{l}\text { Excessive interference from parties in the } \\
\text { implementation of the project. }\end{array}$ & [112-115]. \\
\hline & GPR7 & $\begin{array}{l}\text { Corruption , bribery, and cost for corrupt } \\
\text { government officials }\end{array}$ & $\begin{array}{l}\text { [5-22-43-50-72-78-79-80-82-86-101- } \\
103] .\end{array}$ \\
\hline \multirow{4}{*}{ 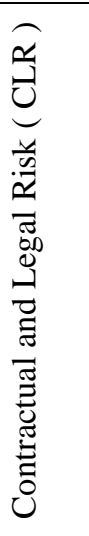 } & CLR1 & $\begin{array}{l}\text { The existence of ambiguous circumstances about } \\
\text { the contract. }\end{array}$ & [5-40-69-79-84-86-87-92-98-112]. \\
\hline & CLR2 & $\begin{array}{l}\text { Unclear clauses/ conditions of contract such as } \\
\text { (dispute resolution method, claims, penalties, } \\
\text { warranty problems, default terminations, intellectual } \\
\text { property infringement charges, disputes, alleged } \\
\text { confidentiality disclosures, and litigation-retained } \\
\text { amounts). }\end{array}$ & [5-22-43-50-60-75-80-81-82-83-94]. \\
\hline & CLR3 & $\begin{array}{l}\text { Insufficient, inefficient and Difference of laws } \\
\text { between partners. Moreover, the legal procedures } \\
\text { relating to the contract. }\end{array}$ & $\begin{array}{l}\text { [5-18-22-40-41-43-57-62-69-72-77-84- } \\
86-101-103] .\end{array}$ \\
\hline & CLR4 & Text in the contract is unfair and unacceptable. & [5-91-94-95-99-101-102-116]. \\
\hline \multirow{6}{*}{ 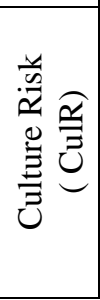 } & CULR1 & Language differences between parties. & [5-7-37-72-82-92-93-101-117]. \\
\hline & CULR2 & Cultural differences between partners. & $\begin{array}{l}\text { [5-7-24-48-69-72-77-82-84-86-92-93- } \\
101-110-117] .\end{array}$ \\
\hline & CULR3 & Social differences between partners. & [24-73-101-113]. \\
\hline & CULR4 & Unfamiliarity with local conditions. & {$[5-50-72-101]$} \\
\hline & CULR5 & Religious Inconsistency between parties & [118]. \\
\hline & CULR6 & Difference in traditions between parties & [118]. \\
\hline
\end{tabular}




\section{GAPS IN LITERATURE REVIEW}

Based on the literature review, the gaps in this study are highlighted as shown in table 1.4. These gaps, transferred and described as research objectives, bridged in this research.

Table 1.4: Research gaps in the literature review (Source: Researcher)

\begin{tabular}{|c|l|c|}
\hline N.O & Research gaps & Research Objective \\
\hline $1-$ & $\begin{array}{l}\text { There have not been many studies related to the construction of oil and } \\
\text { gas production facilities project in onshore. This is the first study of such } \\
\text { projects especially in developing countries such as Yemen. }\end{array}$ & To investigate risk factors in the \\
$2-$ & $\begin{array}{l}\text { The tender process in the construction of oil and gas production facilities } \\
\text { projects has not received much attention from the researchers, so the } \\
\text { researcher tries to focus on this stage of the construction of oil and gas } \\
\text { production facilities. } \\
\text { tender process affecting the contract } \\
\text { implementation stage in onshore oil } \\
\text { and gas production facilities projects. }\end{array}$ & $\begin{array}{l}\text { Most risk studies have focused on risk factors in the project in general or } \\
\text { on risks at the implementation stage. This study attempts to study risks at } \\
\text { the planning stage, especially the tender process affecting the contract's } \\
\text { implantation stage. }\end{array}$ \\
\hline 4- & $\begin{array}{l}\text { There is a number of programs for assessing and evaluating the model. } \\
\text { However, in this research, I used AMOS software, which contains the } \\
\text { latest tools used to verify the validity and reliability of the model and its } \\
\text { applicability. }\end{array}$ \\
\hline
\end{tabular}

\section{RESEARCH METHODOLOGY}

The research methodology is composed of three steps: data collection, data analysis using the SPSS program and data analysis using the AMOS program, as shown in the figure 1.3.

\subsection{Data Collection}

The data collected from the literature review, and questionnaires. The literature review provided background and justification for the research undertaken [98 -119]. A review of the literature has been undertaken using published sources (journals, books, reports, and online publications). Such sources assisted the researcher in acquiring a full insight into the research problem, thereby establishing the research gaps. Also assisted by having a clear picture to deliver relevant questions that pursued through the questionnaires. The questionnaire is a research instrument consisting of a series of questions for gathering information from respondents / current practices [120 - 121]. The questions of the questionnaire may be unstructured or structured, as well as closeended or open-ended [122].

For this research, the questionnaire self-administered, with structured and close-ended questions. The questionnaire divided into two sections, basic information which includes 5 questions and risk factors, which includes 65 questions as shown in table 1.5 .

This research based on an ideal probability sample, namely a "Simple random sampling". The sample size was 400 questionnaire copies distributed to shareholders: " top managers, tender engineers, contracts engineers, planning \& control engineers, estimation engineers, and risks assessment engineers in (national / local government, oil \& gas engineering consultant companies, and local / international oil \& gas companies), who are related to work in oil and gas PFP in Yemen. 209 out of 400 questionnaires were returned from the participant responses. Nine questionnaires not completed (ineligible). This study based on 200 valid responses. The response rate is $51.15 \%$ and it is suitable as stated by [123] that the response rates between $30 \%$ and $50 \%$ are appropriate for delivered and collected questionnaires 
International Journal of Engineering Research And Advanced Technology, Vol.5, Issue 12, December-2019

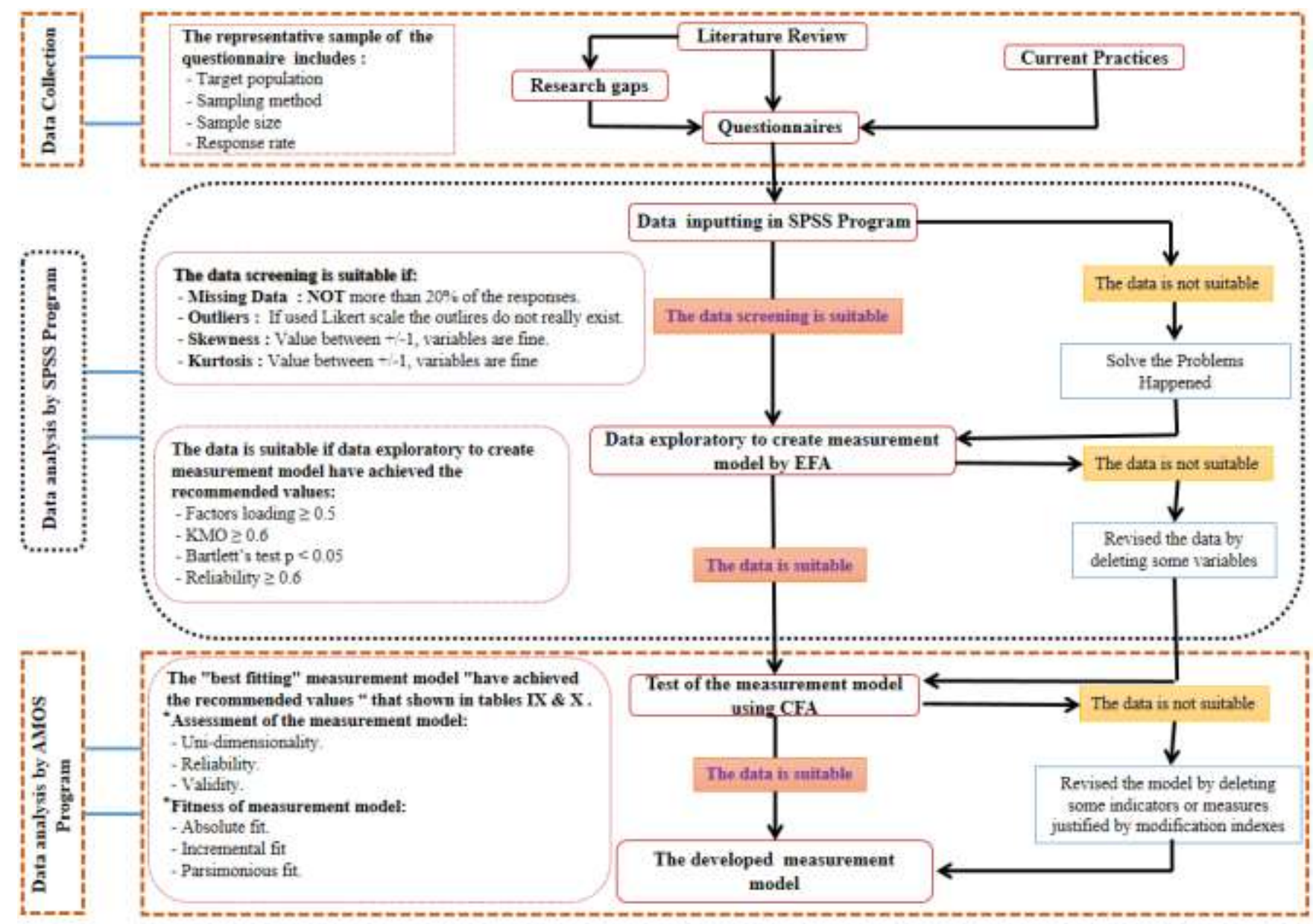

Figure 1.3: Research Methodology (Source: Researchers)

\subsection{Data analysis by SPSS program}

The data that has been gathered by questionnaires and inputted in SPSS Program 21, has been screened and extracted to create a measurement model.

\subsection{Data analysis by Amos program}

The data that extracted by EFA using SPSS Program 21, built a measurement model by Amos program 21 and subjected to CF A program to assess, validate and modify the model to develop the final measurement model.

Table 1.5: Questionnaire categories and number of questions (Source: researcher).

\begin{tabular}{|c|c|c|c|c|c|}
\hline Categories & Items & Identifier & $\begin{array}{l}\text { N.o of que. in } \\
\text { each item }\end{array}$ & $\begin{array}{l}\text { N.o of que. in } \\
\text { each Category }\end{array}$ & $\alpha$ \\
\hline \multirow{5}{*}{ 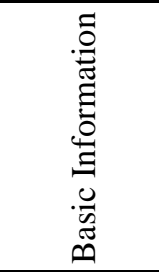 } & Qualification & Qual & 1 & \multirow{5}{*}{5} & \multirow{5}{*}{0.957} \\
\hline & Experience in Oil \& Gas industry & Exper & 1 & & \\
\hline & $\begin{array}{l}\text { Job Position / Responsibility in your Company / Or } \\
\text { ganization. }\end{array}$ & job & 1 & & \\
\hline & Type of your Company / Organization. & TYC & 1 & & \\
\hline & Role of your Company / Organization. & RYC & 1 & & \\
\hline \multirow{9}{*}{ 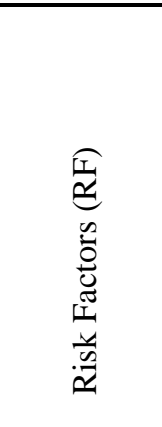 } & Management Risk & MR & 11 & \multirow{9}{*}{65} & \multirow{9}{*}{0.903} \\
\hline & Culture Risk & CULR & 6 & & \\
\hline & Contractual \& Legal Risk & CLR & 4 & & \\
\hline & Organizational Risk & OrR & 7 & & \\
\hline & Risk of Planning \& Estimate & PER & 6 & & \\
\hline & Health, Safety, Environmental, and Quality Risk & HSEQR & 4 & & \\
\hline & Governmental Policy Risk & GPR & 7 & & \\
\hline & Financial \& Economic Risk & FER & 10 & & \\
\hline & Engineering Risk & ER & 10 & & \\
\hline
\end{tabular}




\section{RESULT AND DISCUSSION}

\subsection{Data screening.}

Prior to the data analysis in structural equation modeling, the original data has been screened for possible problems ([124]).

First, [125] reiterated that if missing data is more than $20 \%$ of total engaged items, such respondents should be removed from the study. However, there is no missing value in the data set.

Second, Outliers do not really exist in Likert-scales. Answering at the extreme ( 1 or 5$)$ is not really representative outlier behavior [126 -127].

Third, For the normality test, the rule of thumb is that for data to be normally distributed, the absolute value of skew and kurtosis must not be more than 1 [128]. The normality of the distribution of each indicator tested in terms of skew index (SI) and kurtosis index (KI). The SI ranges between -0.359 and 0.788 , the absolute value of which is less than the recommended level of $1[128]$. The interim for KI is between -0.981 and 0.688 , whose absolute value is less than 1 [128]. Therefore, all study indicators are normally distributed. No items exceed that cut off point suggested by previous authors. Thus, the screening data is suitable for exploratory factor analysis.

\subsection{Exploratory Factor Analysis (EFA)}

After the suitable results of data that has been inserted and screened by SPSS 21, the process continues to extract the data of creating a measurement model by EFA. The EFA is a technique / method of factor loading into groups to extract underlying latent factors, or for grouping variables together on a factor or a precise number of factors [129 -130]. In order to achieve suitable EFA results, [130] recommends that the factor loading estimates should be higher than 0.6. Also, [131 - 132] recommend calculating the Kaiser-Meyer-Olkin (KMO) examination to measure the sampling adequacy and Bartlett's Test of Sphericity. The value of $\mathrm{KMO}$, which is greater than 0.6, suggests that the relationship between items is statistically significant and appropriate for EFA; and $\mathrm{KMO}$ which is lower than 0.6, is not suitable, hence, the EFA should not be performed. Although the significance of Bartlett's test of sphericity indicates that the significance at $(\mathrm{P}<0.05)$, for the EFA to be considered appropriate; and (Bartlett's test), which is greater than $(\mathrm{P}>0.05)$ is not suitable; hence the EFA should not be performed [133].

In this study, table 1.6 shows the data that created a measurement model, which indicates 60 items loading factor (greater than 0.6) are accepted, and 5 items loading factor (less than 0.6) are rejected.

Table 1.6: Rotated Factor Matrix ( Loading factors) ( Source: Field data analysis - researcher )

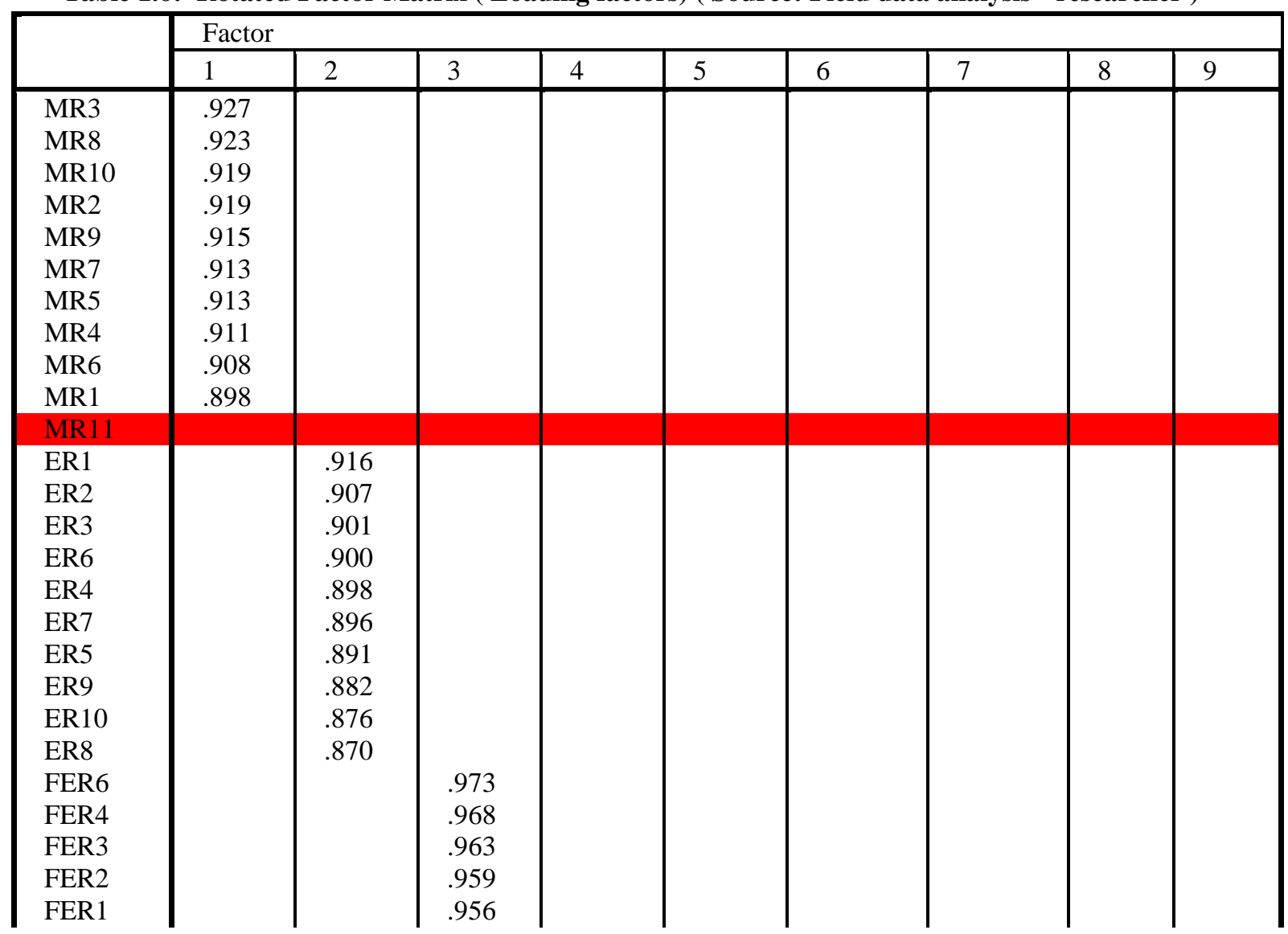


International Journal of Engineering Research And Advanced Technology, Vol.5, Issue 12, December-2019

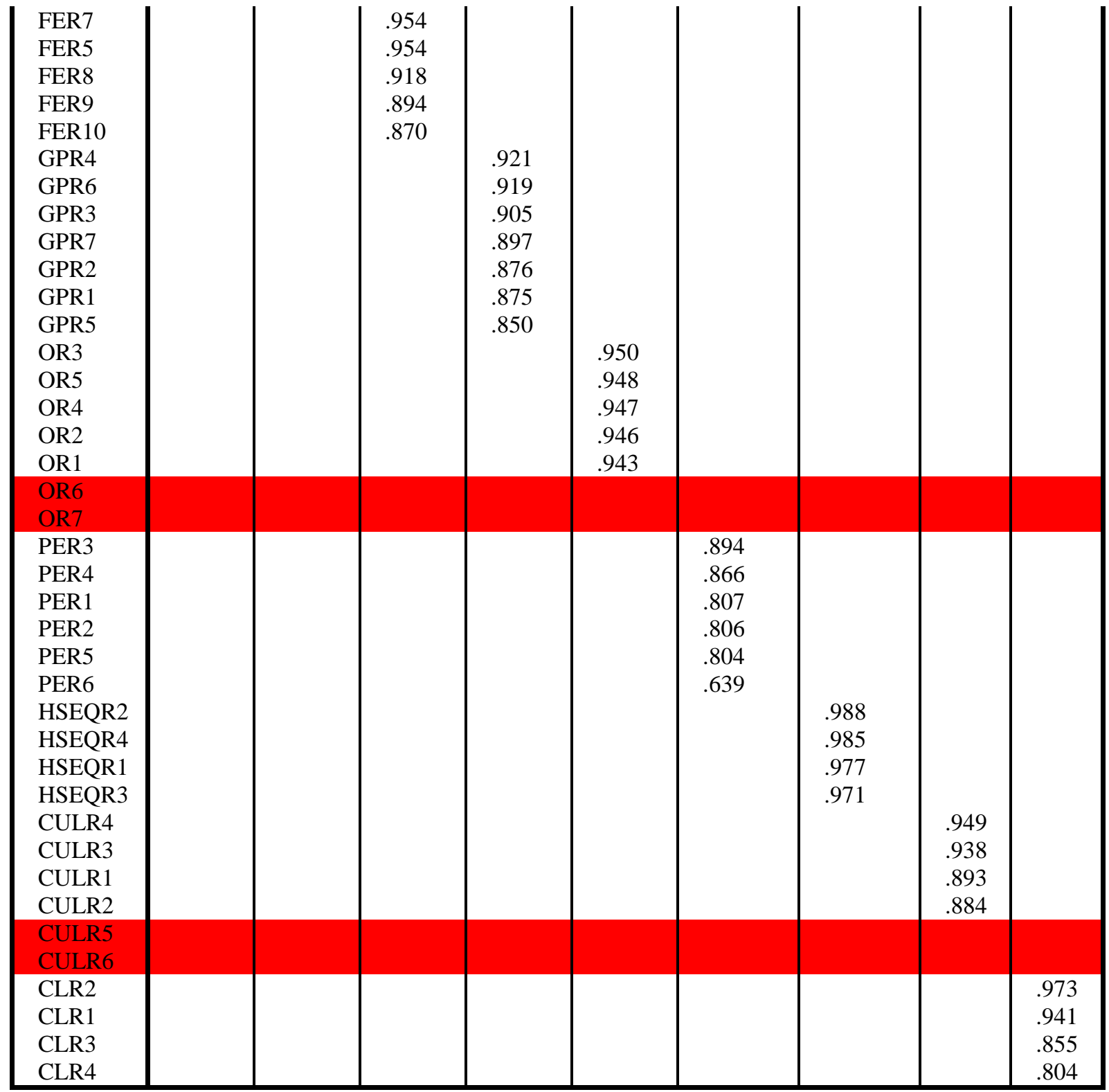

For the accepted items, as shown in table 1.7, the KMO $=0.902$ (greater than 0.6), thus the relationship between items is statistically significant, and Bartlett's Test $(\mathrm{P}=0.000)($ less than 0.05$)$ is statistically significant too; hence the EFA is appropriate, suitable, and should be performed [133].

Table 1.7: KMO and Bartlett's Test (Source: Field data analysis - researcher)

\begin{tabular}{|l|l|l|}
\hline Kaiser-Meyer-Olkin Measure of Sampling Adequacy.(KMO) & 0.902 \\
\hline Bartlett's Test of Sphericity & Approx. Chi-Square & 22235.447 \\
\cline { 2 - 3 } & $\mathrm{df}$ & 1770 \\
\cline { 2 - 3 } & Sig. & 0.000 \\
\hline
\end{tabular}

Based on table 1.8, the internal reliability of the constructs has been correspondingly in the comfortable range as the Cronbach's alpha value of all the constructs exceed the suggested level of 0.60; where: $(\mathrm{MR}=0.993 ; \mathrm{FER}=0.992 ; \mathrm{FER}=0.989 ; \mathrm{GPR}=0.967$; $\mathrm{OR}=0.995 ; \mathrm{PER}=0.919 ; \mathrm{HSEQR}=0.994 ; \mathrm{CULR}=0.963 ; \mathrm{CLR}=0.949)$. All the above results analyzed by SPSS 21 indicate that these factors are considered as the basis for the CFA application [132].

\subsection{Confirmatory Factor Analysis (CFA)}

After ensuring the data that extracted by EFA, such data created a measurement model by Amos 21. CFA is a statistical technique used to verify the factor structure of a set of observed variables and study the relationship between these variables, as well as their existing underlying latent constructs [134].

According to [135-136], the items of the constructs undergo the CFA procedure that involves a uni-dimensionality test, convergent validity, construct validity and discriminant validity, using Amos program 21, and the criteria indicator as shown in 
table 1.6. All such is followed by measurement of reliability on all items using the SPSS Program to ensure the consistency of the measurement model, and to measure the constructs that could not be measured directly [137].

Table 1.8. Assessment of the measurement model

\begin{tabular}{|l|l|l|l|}
\hline \multicolumn{1}{|l|}{ Assessment } & Criterion & Name of Index & Level of Acceptance \\
\hline yni-dimensionalit & Factor loading & Standardized Regression Weight & Weight $\geq 0.6$ \\
\hline \multirow{3}{*}{ Validity } & Construct validity & See table 1.10. & \multicolumn{2}{|c|}{ AVE $\geq 0.5$} \\
\cline { 2 - 4 } & Convergent validity & $\begin{array}{c}\text { Average Variance Extracted (AV } \\
\text { E ) }\end{array}$ & \multicolumn{2}{|c|}{ CR $\geq 0.6$} \\
\cline { 2 - 4 } & Discriminant validity & $\leq 0.85$ & $\alpha \geq 0.6$ \\
\hline \multirow{2}{*}{ Reliability } & Construct Reliability & CR & Cronbach Alpha $(\alpha)$ \\
\cline { 2 - 4 } & Internal Reliability & CR & \\
\hline
\end{tabular}

Source of this table adapted from: [31-124-130-132-136-138-139].

According to [31], the equations of (AVE) and (CR) are as follows:

$$
\begin{aligned}
& \mathrm{AVE}=\frac{\sum \mathrm{K}^{2}}{\mathrm{n}}------------------(1) \\
& \mathrm{CR}=\frac{\sum \mathrm{K}^{2}}{\left[\left(\sum \mathrm{K}\right)^{2}+\left(\sum 1-\mathrm{K}^{2}\right)\right]}-------------(2)
\end{aligned}
$$

Where: $\mathrm{K}=$ factor loading of every item, $\mathrm{n}=$ number of items in a model.

Assessments of the measurement model.

To check the uni-dimension of all construct items that are initially created by Amos program, all measuring items have positive and acceptable factor loadings (greater than 0.6) as shown in table 1.9 and figure 1.4

\begin{tabular}{|c|c|c|c|c|c|}
\hline Construct & Item & Factor Loading & $\begin{array}{c}\text { Cronbach's Alpha } \\
(\alpha)\end{array}$ & CR & AVE \\
\hline \multirow{11}{*}{$\begin{array}{l}\text { Management Risk } \\
\text { ( MR) }\end{array}$} & MR3 & .927 & \multirow{11}{*}{0.993} & \multirow{11}{*}{0.981} & \multirow{11}{*}{0.836} \\
\hline & MR8 & .923 & & & \\
\hline & MR10 & .919 & & & \\
\hline & MR2 & .919 & & & \\
\hline & MR9 & .915 & & & \\
\hline & MR7 & .913 & & & \\
\hline & MR5 & .913 & & & \\
\hline & MR4 & .911 & & & \\
\hline & MR6 & .908 & & & \\
\hline & MR1 & .898 & & & \\
\hline & MR11 & Deleted & & & \\
\hline \multirow{10}{*}{$\begin{array}{l}\text { Engineering Risk } \\
\text { ( ER ) }\end{array}$} & ER1 & .916 & \multirow{10}{*}{0.992} & \multirow{10}{*}{0.975} & \multirow{10}{*}{0.799} \\
\hline & ER2 & .907 & & & \\
\hline & ER3 & .901 & & & \\
\hline & ER6 & .900 & & & \\
\hline & ER4 & .898 & & & \\
\hline & ER7 & .896 & & & \\
\hline & ER5 & .891 & & & \\
\hline & ER9 & .882 & & & \\
\hline & ER10 & .876 & & & \\
\hline & ER8 & .870 & & & \\
\hline \multirow{9}{*}{$\begin{array}{c}\text { Financial \& Economic Risk } \\
\text { ( FER ) }\end{array}$} & FER6 & .973 & \multirow{9}{*}{0.989} & \multirow{9}{*}{0.987} & \multirow{9}{*}{0.887} \\
\hline & FER4 & .968 & & & \\
\hline & FER3 & .963 & & & \\
\hline & FER2 & .959 & & & \\
\hline & FER1 & .956 & & & \\
\hline & FER7 & .954 & & & \\
\hline & FER5 & .954 & & & \\
\hline & FER8 & .918 & & & \\
\hline & FER9 & .894 & & & \\
\hline
\end{tabular}

Table 1.9: Summary of all Construct, factors loading, $\alpha$, CR, and AVE (Source: Field data analysis - researcher) 
International Journal of Engineering Research And Advanced Technology, Vol.5, Issue 12, December-2019

\begin{tabular}{|c|c|c|c|c|c|}
\hline & FER10 & .870 & & & \\
\hline \multirow{7}{*}{$\begin{array}{c}\text { Governmental Policy Risk } \\
\text { (GPR) }\end{array}$} & GPR4 & .921 & \multirow{7}{*}{0.967} & \multirow{7}{*}{0.965} & \multirow{7}{*}{.796} \\
\hline & GPR6 & .919 & & & \\
\hline & GPR3 & .905 & & & \\
\hline & GPR7 & .897 & & & \\
\hline & GPR2 & .876 & & & \\
\hline & GPR1 & .875 & & & \\
\hline & GPR5 & .850 & & & \\
\hline \multirow{7}{*}{$\begin{array}{l}\text { Organizational Risk } \\
\text { ( OR ) }\end{array}$} & OR3 & .950 & \multirow{7}{*}{0.995} & \multirow{7}{*}{0.977} & \multirow{7}{*}{0.896} \\
\hline & OR5 & .948 & & & \\
\hline & OR4 & .947 & & & \\
\hline & OR2 & .946 & & & \\
\hline & OR1 & .943 & & & \\
\hline & OR6 & Deleted & & & \\
\hline & OR7 & Deleted & & & \\
\hline \multirow{6}{*}{$\begin{array}{l}\text { Risk of Planning \& Estimate } \\
\text { ( PER ) }\end{array}$} & PER3 & .894 & \multirow{6}{*}{0.919} & \multirow{6}{*}{0.917} & \multirow{6}{*}{0.651} \\
\hline & PER4 & .866 & & & \\
\hline & PER1 & .807 & & & \\
\hline & PER2 & .806 & & & \\
\hline & PER5 & .804 & & & \\
\hline & PER6 & .639 & & & \\
\hline \multirow{4}{*}{$\begin{array}{c}\text { Health , Safety, Environment } \\
\text { al, and Quality Risk } \\
\text { ( HSEQR ) }\end{array}$} & HSEQR2 & .988 & \multirow{4}{*}{0.994} & \multirow{4}{*}{0.990} & \multirow{4}{*}{0.961} \\
\hline & HSEQR4 & .985 & & & \\
\hline & HSEQR1 & .977 & & & \\
\hline & HSEQR3 & .971 & & & \\
\hline \multirow{6}{*}{$\begin{array}{l}\text { Culture Risk } \\
\text { (CULR) }\end{array}$} & CULR4 & .949 & \multirow{6}{*}{0.963} & \multirow{6}{*}{0.954} & \multirow{6}{*}{0.840} \\
\hline & CULR3 & .938 & & & \\
\hline & CULR1 & .893 & & & \\
\hline & CULR2 & .884 & & & \\
\hline & CULR5 & Deleted & & & \\
\hline & CULR6 & Deleted & & & \\
\hline \multirow{4}{*}{$\begin{array}{c}\text { Contractual \& Legal Risk } \\
\text { ( CLR ) }\end{array}$} & CLR2 & .973 & \multirow{4}{*}{0.949} & \multirow{4}{*}{0.942} & \multirow{4}{*}{0.803} \\
\hline & CLR1 & .941 & & & \\
\hline & CLR3 & .855 & & & \\
\hline & CLR4 & .804 & & & \\
\hline
\end{tabular}

According to [139] having an acceptable overall model fit, the next phase of CFA is to assess the psychometric properties of measures regarding construct validity, convergent validity, discriminant validity, and reliability properties.

The construct validity is achieved when the three fitness indexes (Absolute fit, Incremental fit, and Parsimonious fit) for a construct achieve the required level [31], as shown in table 1.10. To check the adequacy and fitness of the measurement model in the first running, the goodness of fit indexes are obtained for each construct as shown in table 1.10 (Initial model). The Initial measurement model developed by Modification Indices (MI) for covariance. In the second running, the goodness of fit indexes obtained as shown in table 1.10 (Developed model). Therefore, the measurement model has an acceptable overall model fit. (The fitness indexes, their respective categories, and the level of acceptance presented in table 1.10 are at the required level).

Table 1.10. The three categories of model fit and their level of acceptance (Source: Field data analysis - researcher)

\begin{tabular}{|l|l|l|l|l|l|}
\hline Name of category & Name of index & Level of acceptance** & Initial & Developed & Status \\
\hline \multirow{3}{*}{ 1. Absolute fit } & Chi-Square at (P-value $<0.05)$ & $\chi 2$ at $(\mathrm{P}>0.05)$ & 0.000 & 0.000 & Acceptable \\
\cline { 2 - 6 } & RMSEA & RMSEA $<0.08$ & 0.063 & 0.050 & Acceptable \\
\cline { 2 - 6 } & GFI & GFI $>0.90$ & 0.891 & 0.914 & Acceptable \\
\hline \multirow{3}{*}{ 2. Incremental fit } & AGFI & AGFI $>0.90$ & 0.896 & 0.919 & Acceptable \\
\cline { 2 - 6 } & CFI & CFI $>0.90$ & 0.944 & 0.965 & Acceptable \\
\cline { 2 - 6 } & TLI & TLI $>0.90$ & 0.940 & 0.962 & Acceptable \\
\cline { 2 - 6 } & NFI & NFI $>0.90$ & 0.880 & 0.900 & Acceptable \\
\hline 3. Parsimonious fit & Chisq/df & Chi-Square/ df $<3.0$ & 1.777 & 1.490 & Acceptable \\
\hline
\end{tabular}

${ }^{* *}$ Source of the level acceptance adapted from :[31-124-129-130-136-138-139]. 
The convergent validity verified by computing the Average Variance Extracted (AVE) for every construct by Equation. (1). the value of $(A V E \geq 0.5)$ for this validity to achieve [31-124], and as shown in table 1.8. Table 1.9 shows all the AVE greater than 0.5 , hence the convergent validity is valid for all constructs.

The discriminant validity compares between correlations of constructs ( $r$ ) and the square roots of the average variance extracted ( $\sqrt{\text { AVE }}$ ) for a construct. The Fornell-Larcker criterion then indicates that discriminant validity established if the following condition / Equation (3) holds:

$$
\sqrt{ } \mathrm{AVE}>\max |\mathrm{r}|
$$

The value recommended by [124] the correlations between factors must be less than 0.85 .

Discriminant validity values for the developed measurement model are set out in table 1.11. The correlations between deconstructs range from (-.214 to .591$)$. They also depict that the ( $\sqrt{ }$ AVE $)$ are all greater than the correlations between the latent constructs. Hence, it is below the threshold 0.85 ; hence, this study proposes adequate discriminant validity.

Table 1.11: Summary of discriminant validity index for the measurement model (Source: Field data analysis researcher)

\begin{tabular}{|l|l|l|l|l|l|l|l|l|l|}
\hline & \multicolumn{1}{|c|}{ MR } & ER & FER & GPR & OR & PER & HSEQR & CULR & CLR \\
\hline MR & .914 & & & & & & & & \\
\hline ER & .591 & .894 & & & & & & & \\
\hline FER & -.135 & -.214 & .942 & & & & & & \\
\hline GPR & .116 & .186 & -.105 & .892 & & & & & \\
\hline OR & .343 & .397 & -.144 & .167 & .947 & & & & \\
\hline PER & -.180 & -.171 & -.105 & -.140 & -.181 & .806 & & & \\
\hline HSEQR & -.103 & .157 & -.119 & .119 & -.105 & -.160 & .980 & & \\
\hline CULR & .188 & .179 & .147 & -.177 & .131 & .137 & -.161 & .917 & \\
\hline CLR & .143 & .123 & -.185 & .113 & -.182 & .125 & -.167 & .143 & .896 \\
\hline
\end{tabular}

Risk factors (60 items and 9 constructs construct) are acceptable for validity, reliability, and goodness of fit.

The assessment for reliability of a measurement model is made using the criteria $(\alpha \geq 0.7$; and CR $\geq 0.6)$ [31].

The ( $\alpha$ calculated in SPSS; and CR calculated using the given formula in Equation (2)). the results shown in table 1.9 are acceptable values for ( $\alpha$; and CR).Therefore, the assessment for reliability of measurement model is good and acceptable.

Accordingly, investigating risk factors (60 items and 9 constructs) are acceptable for validity, reliability, and goodnes s of fit.

\section{CONCLUSION}

The purpose of this study to investigate and identify RFs, in a tender process, affecting the contract implementation stage in onshore oil and gas production facilities projects. SPSS Program has subjected all the 65 risk factors, collected by literature review and survey, to EFA. The risk factors that are not statistically significant have been removed. The remaining 60 out of 65 of risk factors, constructed in nine latent constructs, are statistically significant. In addition, the 60 risk factors in nine constructs that mentioned in table 1.9 subjected to CFA, by Amos Program, to test factor-loading, uni-dimension, assessment of the overall goodness-of-fit, validity, and reliability. All the 60 risk factors, in the nine constructs involved, have achieved the factor loading > 0.6 , assessment of the overall goodness-of-fit, validity, and reliability. Thus, the findings of this study in figure 1.4 are very significant.

This finding of risk factors is a very important guide for practice and academics, for it provides useful information to those looking for the current state of knowledge on risk factors, in the tender process affecting the contract implementation stage, in oil and gas production facilities projects. It also helps in achieving better attention and allocation of risk factors, for better treatment and good control in the planning and implementation stage. Moreover, it provides support for risk analysis in future projects, in addition to understanding more of RFs in developing countries. 
International Journal of Engineering Research And Advanced Technology, Vol.5, Issue 12, December-2019

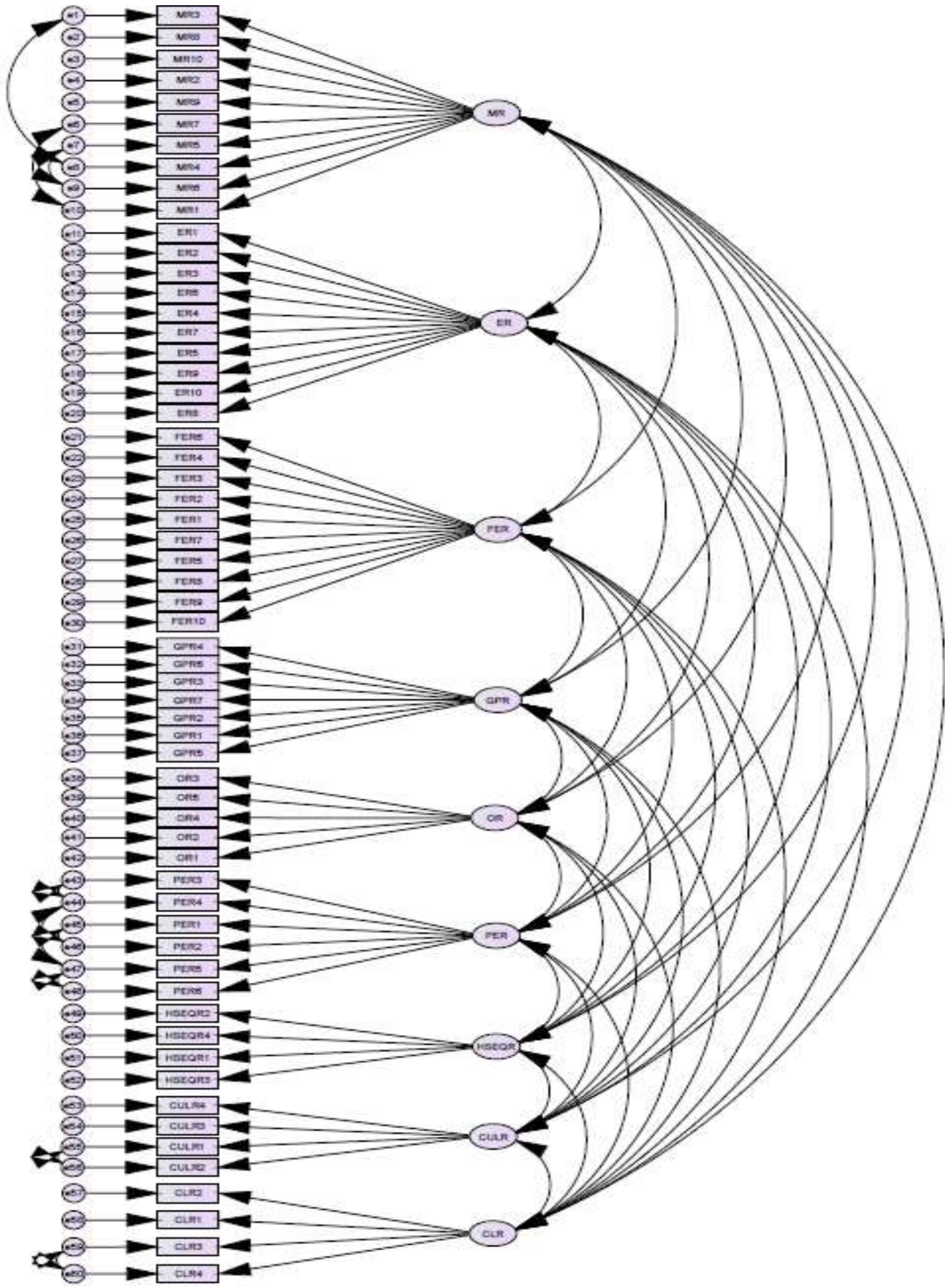

Figure 1.4. The developed measurement model of risk factors (Source: Field data analysis - researcher) 


\section{REFERENCES}

[1] D. C. Sylvester, N. S. A. Rani, and J. M. Shaikh, "Comparison between oil and gas companies and contractors against cost, time, quality and scope for project success in Miri, Sarawak, Malaysia," African J. Bus. Manag., vol. 5, no. 11, pp. 4337-4354, 2011.

[2] CAPP, Canadian Association of Petroleum Producer, 2013.

[3] M. Ramabhadran, "An Investigation into Cost Overrun in Construction Projects in United Arab Emirates," Int. J. Constr. Eng. Manag., vol. 7, no. 1, pp. 1-21, 2018.

[4] M. Moazzami, J. Y. Ruwanpura, and G. F. Jergeas, "Conversion method for applying convertible contracts in oil and gas projects," 2013.

[5] M. A. Khoiry, M. A. Kassem, and N. Hamzah, "A pilot study on identify risk factors in oil \& gas," Int. J. Adv. Mech. Civ. Eng., vol. 5, no. 4, pp. 1-6, 2018.

[6] E. L. Ledezema, I. Nataly, and Q. Fernandez, Risk Management in the Bidding Process, 2012.

[7] M. A. L. I. Atefi, "Assessment of Risk Factors of a Completed Oil and Gas Project, with the Use of a Hybrid EVM-SAW Method,” J. Energy Manag. Technol., vol. 2, no. 1, pp. 42-53, 2018.

[8] E. A. S. Altyib and A. A. Alhakim, "Types of risk in oil field EPCC construction projects in Sudan," Am. J. Res. Commun., vol. 6, no. 10, 2018.

[9] S. B. Suslick and D. J. Schiozer, "Risk analysis applied to petroleum exploration and production: an overview," $J$. Pet. Sci. Eng., vol. 44, no. 1-2, pp. 1-9, 2004.

[10] T. Compernolle, K. Welkenhuysen, K. Huisman, K. Piessens, and P. Kort, "Off-shore enhanced oil recovery in the North Sea: The impact of price uncertainty on the investment decisions," Energy Policy, vol. 101, pp. 123137, 2017.

[11] N. J. Smith, T. Merna, and P. Jobling, Managing risk in construction projects, 2014.

[12] J. Agerberg, Risk management in the tendering process, 2012.

[13] C. W. Lou Eric and A. Mustafa, "Critical success factors for e-tendering Implementation in construction collaborative environments: people and process issues," Electron. J. Inf. Technol. Constr., vol. 14, no. May, pp. 98-109, 2009.

[14] C. Vee and Cm. Skitmore, "Professional ethics in the construction industry," Eng. Constr. Archit. Manag., vol. 10, no. 2, pp. 117-127, 2003.

[15] J. Egan, "Rethinking construction, construction task force report for department of the environment, transport and the regions," 1998.

[16] R. Du, E. Foo, C. Boyd, and B. Fitzgerald, "Defining security services for electronic tendering,” 2004.

[17] S. A. Burtonshaw-Gunn, Risk and financial management in construction. 2017.

[18] R. C. Marques and S. Berg, "Risks, contracts, and private-sector participation in infrastructure," J. Constr. Eng. Manag., vol. 137, no. 11, pp. 925-932, 2011.

[19] K. Larkin, H. Odeyinka, and R. Eadie, "An exploration of theoretical concepts and methods for assessing risk impacts on the variability between contract sum and final account in design and build projects," Assoc. Res. Constr. Manag., vol. 1, pp. 337-346, 2012.

[20] H. P. Chandra, "Structural equation model for investigating risk factors affecting project success in Surabaya," Procedia Eng., vol. 125, pp. 53-59, 2015.

[21] B. C. Schramm, A. Meißner, and G. Weidinger, "Contracting strategies in the oil and gas industry," Pipeline Technol., pp. 3-6, 2010.

[22] N. Van Thuyet, S. O. Ogunlana, and P. K. Dey, "Risk management in oil and gas construction projects in Vietnam," Int. J. energy Sect. Manag., vol. 1, no. 2, pp. 175-194, 2007.

[23] S. Mubin, "Innovative approach to risk analysis and management of oil and gas sector EPC contracts from a contractor' s perspective," J. Bus. Econ., vol. 5, no. 2, pp. 149-170, 2013.

[24] M. Zaripour and B. Zaripour, "Risk management in industrial projects using structural equation modeling," Manag. Sci. Lett., pp. 599-608, 2016.

[25] S. Prabhakar and P. Q. Manager, "Risk Management and its positive impacts on efficiencies and saving jobs in Oil and Gas Industry," Int. J. Adv. Res. Trends Eng. Technol., vol. 4, no. 5, 2017. 
[26] M. A. Kassem, M. A. Khoiry, and N. Hamzah, "Evaluation of risk factors affecting on oil and gas construction projects in Yemen," Int. J. Eng. Technol., vol. 8, pp. 6-14, 2019.

[27] G. Dehdasht, R. Mohamad Zin, M. Ferwati, M. Mohammed Abdullahi, A. Keyvanfar, and R. McCaffer, "DEMATEL-ANP risk assessment in oil and gas construction projects," Sustainability, vol. 9, no. 8, p. 1420, Aug. 2017.

[28] F. Zhang, W. Wang, and S. Xu, Six kinds of bidding risk prediction model based on multiple attribute decisionmaking theories and Its application, 2014.

[29] D. Samuel, "Predicting significant contract risks at the tender evaluation stage," Proc. Inst. Civ. Eng. Procure. Law, vol. 167, no. 2, pp. 100-107, 2014.

[30] J. Wong, R. Berkelaar, and H. Pekelharing, Integral risk management for DBFM tenders and contracts in the Netherlands, 2015.

[31] Z. Awang, A Handbook on structural equation modelling using AMOS, 2012.

[32] M. Karimimalayer, "Structural equation modeling VS multiple regression," IRACST - Eng. Sci. Technol. An Int. J., vol. 2, no. 2, pp. 326-329, 2012.

[33] S. H. Han, D. Y. Kim, H. Kim, and W.-S. Jang, "A web-based integrated system for international project risk management," Autom. Constr., vol. 17, no. 3, pp. 342-356, 2008.

[34] K. M. Cho, T. H. Hong, and C. T. Hyun, "Effect of project characteristics on project performance in construction projects based on structural equation model," Expert Syst. Appl., vol. 36, no. 7, pp. 10461-10470, 2009.

[35] D. A. Patel and K. N. Jha, "Structural equation modeling for relationship-based determinants of safety performance in construction projects," J. Manag. Eng., vol. 32, no. 6, p. 5016017, 2016.

[36] A. D. Mohammad, F M and Price, "Multi-cultural complexity impact on procurement within the oil and gas sector," 2005.

[37] M. Hastak and A. Shaked, "ICRAM-1: Model for international construction risk assessment," J. Manag. Eng., vol. 16, no. 1, pp. 59-69, 2000.

[38] N. A. Kartam and S. A. Kartam, "Risk and its management in the Kuwaiti construction industry: a contractors perspective," Int. J. Proj. Manag., vol. 19, no. 6, pp. 325-335, 2001.

[39] H. M. Al Tabtabai, Causes for delays in construction projects in Kuwait, 2002.

[40] A. M. Odeh and H. T. Battaineh, "Causes of construction delay: traditional contracts," Int. J. Proj. Manag., vol. 20, no. 1, pp. 67-73, 2002.

[41] M. Wang, M. Asce, and H. Chou, "Risk allocation and risk handling of highway projects in Taiwan," J. Manag. Eng., vol. 19, no. April, pp. 60-68, 2003.

[42] N. D. Long, S. Ogunlana, T. Quang, and K. C. Lam, "Large construction projects in developing countries: a case study from Vietnam,” Int. J. Proj. Manag., vol. 22, no. 7, pp. 553-561, 2004.

[43] S. A. Assaf and S. Al-Hejji, "Causes of delay in large construction projects," Int. J. Proj. Manag., vol. 24, no. 4, pp. 349-357, 2006.

[44] A. A. Aibinu and H. A. Odeyinka, "Construction delays and their causative factors in Nigeria," J. Constr. Eng. Manag., vol. 132, no. 7, pp. 667-677, 2006.

[45] I. A. Majid, Causes and effects of delays in ACEH construction industry, 2006.

[46] M. Sambasivan and Y. W. Soon, "Causes and effects of delays in Malaysian construction industry," Int. J. Proj. Manag., vol. 25, no. 5, pp. 517-526, 2007.

[47] A. Sweis, G., Sweis, R., Abu Hammad, A., Shboul, "Delays in construction projects: The case of Jordan.," Int. J. Proj. Manag., vol. 26, pp. 665-674, 2008.

[48] S. M. El-Sayegh, "Risk assessment and allocation in the UAE construction industry," Int. J. Proj. Manag., vol. 26, no. 4, pp. 431-438, May 2008.

[49] N. Azhar, R. U. Farooqui, and S. M. Ahmed, "Cost overrun factors in construction industry of Pakistan," 2008.

[50] A. Enshassi, S. Mohamed, and S. Abushaban, "Factors affecting the performance of construction projects in the Gaza strip,” J. Civ. Eng. Manag., vol. 15, no. 3, pp. 269-280, 2009.

[51] A. Al-Kharashi and M. Skitmore, "Causes of delays in Saudi Arabian public sector construction projects," Constr. Manag. Econ., vol. 27, no. 1, pp. 3-23, 2009.

[52] S. A. H. Tumi and A. Omran, Causes of delay in construction, 2015. 
[53] A. A.-B. F. Fugar, "Delays in building construction projects in Ghana," Australas. J. Constr. Econ. Build., vol. 10, no. (1/2), pp. 103-116, 2010.

[54] A. H. Memon, I. A. Rahman, M. R. Abdullah, and A. A. A. Azis, "Factors affecting construction cost performance in project management projects :Perspective of Project Management Consultant," Int. J. Sustain. Constr. Eng. Technol., vol. 1, no. 2, pp. 30-35, 2010.

[55] G. D. Creedy, M. Skitmore, and J. K. W. Wong, "Evaluation of risk factors leading to cost overrun in delivery of highway construction projects," J. Constr. Eng. Manag., vol. 136, no. 5, pp. 528-537, 2010.

[56] A. Hyder, A. Azhar, A. Javaid, and M. Rehman, Entrepreneurial intentions among business students in Pakistan, 2011.

[57] D. W. M. Chan, A. P. C. Chan, P. T. I. Lam, and J. M. W. Wong, "An empirical survey of the motives and benefits of adopting guaranteed maximum price and target cost contracts in construction," Int. J. Proj. Manag., vol. 29, no. 5, pp. 577-590, 2011.

[58] M. Murray, M. Seif, and W. Umaru, "Causes of project delays in Nigerian construction industry," Eur. J. Civ. Eng. Archit., vol. 10, no. 1, pp. 1-7, 2013.

[59] O. E. Akinsiku and A. Akinsulire, "Stakeholders perception of the causes and effects of construction delays on project delivery," J. Constr. Eng. Proj. Manag., vol. 2, no. 4, pp. 25-31, 2012.

[60] P. Rezakhani, "Fuzzy MCDM model for risk factor selection in construction projects," Eng. J., vol. 16, no. 5, pp. 79-94, 2012.

[61] Nazaha, National anti- corruption commission, government projects falter; their causes and means of reducing them, 2013.

[62] H. Hashemi, S. M. Mousavi, R. Tavakkoli-Moghaddam, and Y. Gholipour, "Compromise ranking approach with bootstrap confidence intervals for risk assessment in port management projects," J. Manag. Eng., vol. 29, no. 4, 2013.

[63] M. M. Marzouk and T. I. El-rasas, "Analyzing delay causes in Egyptian construction projects Analyzing delay causes in Egyptian construction projects," J. Adv. Res., vol. 5, no. 1, pp. 49-55, 2014.

[64] M. Gündüz, Y. Nielsen, and M. Özdemir, "Quantification of delay factors using the relative importance index method for construction projects in Turkey," J. Manag. Eng., vol. 29, no. 2, pp. 133-139, 2012.

[65] I. A. Rahman, A. H. Memon, and A. T. A. Karim, "Examining factors affecting budget overrun of construction projects undertaken through management procurement method using PLS-sem approach," Procedia - Soc. Behav. Sci., vol. 107, pp. 120-128, 2014.

[66] S. K. Pai and J. R. Bharath, "Analysis of critical causes of delays in Indian infrastructure projects," Int. J. Innov. Res. Dev., vol. 2, no. 3, pp. 251-263, 2013.

[67] S. Sorooshian, "Delay-based reliability analysis on construction projects," Life Sci. J., vol. 11, no. 3, pp. 104$113,2014$.

[68] R. Hasan, S. M. A. Suliman, and Y. Al Malki, “An investigation into the delays in road projects in Bahrain," Int. J. Res. Eng. Sci., vol. 2, no. 2, pp. 38-47, 2014.

[69] S. M. El-Sayegh and M. H. Mansour, "Risk assessment and allocation in highway construction projects in the UAE,” J. Manag. Eng., vol. 31, no. 6, pp. 04015004-11, 2015.

[70] L. T. Van, N. M. Sang, and N. T. Viet, "A conceptual model of delay factors affecting government construction projects,” ARPN J. Sci. Technol., vol. 5, no. 2, pp. 92-100, 2015.

[71] U. H. Issa, M. A. Farag, L. M. Abdelhafez, and A. Ahmed, S., "A risk allocation model for construction projects in Yemen," Civ. Environ. Res., vol. 7, no. 3, pp. 78-89, 2015.

[72] J. Liu, X. Zhao, and P. Yan, "Risk paths in international construction projects: Case study from Chinese contractors," J. Constr. Eng. Manag., vol. 142, no. 6, p. 05016002, 2016.

[73] A. K. S. Dineshkumar B, Deiveegan A, "Estimation of construction phase risk in roadways project," Int. J. Adv. Res. Eng. Technol. Vol., vol. 9, no. 1, pp. 33-42, 2018.

[74] J. U. Wilson and I. A. Odesola, "Design-related causes of rework and the performance of oil and gas projects in Nigeria," Int. J. Sustain. Constr. Eng. Technol., vol. 8, no. 1, pp. 60-76, 2017.

[75] D. Hillson, Use a RBS to understand your risks, 2002.

[76] A. Mousa and J. Hmaid, "Risk management in construction projects from contractors and owners' perspectives," Risk Manag. Constr. Proj. from Contract. Owners’ Perspect., 2005. 
[77] I. Dikmen, M. T. Birgonul, and S. Han, "Using fuzzy risk assessment to rate cost overrun risk in international construction projects," Int. J. Proj. Manag., vol. 25, no. 5, pp. 494-505, 2007.

[78] K. N. Jha and M. N. Devaya, "Modelling the risks faced by Indian construction companies assessing international projects," Constr. Manag. Econ., vol. 26, no. 4, pp. 337-348, 2008.

[79] H. Subramanyan, P. H. Sawant, and V. Bhatt, "Construction project risk assessment: development of model based on investigation of opinion of construction project experts from India," J. Constr. Eng. Manag., vol. 138, no. 3, pp. 409-421, 2012.

[80] D. Baloi and A. D. F. Price, "Modelling global risk factors affecting construction cost performance," Int. J. Proj. Manag., vol. 21, no. 4, pp. 261-269, 2003.

[81] K. S. Sultan B., "Local problems in the construction industry of Yemen," Proc. Int. Symp. Glob. Constr, 2004.

[82] S. Q. Wang, M. F. Dulaimi, and M. Y. Aguria, "Risk management framework for construction projects in developing countries," Constr. Manag. Econ., vol. 22, no. 3, pp. 237-252, 2004.

[83] S. Wiguna, I.P.A. and Scott, "Analyzing the risks affecting construction delay and cost overruns in Indonesia building projects," Innov. Archit. Eng. Constr., pp. 841-849, 2005.

[84] I. Dikmen and M. T. Birgonul, "An analytic hierarchy process based model for risk and opportunity assessment of international construction projects," Can. J. Civ. Eng., vol. 33, no. 1, pp. 58-68, 2006.

[85] M. E. Abd El-Razek, H. A. Bassioni, and A. M. Mobarak, "Causes of delay in building construction projects in Egypt,” J. Constr. Eng. Manag., vol. 134, no. 11, pp. 831-841, 2008.

[86] M. T. Bu-Qammaz, A. S., Dikmen, I., and Birgonul, "Risk assessment of international construction projects using the analytic network process," Can. J. Civ. Eng, pp. 1170-1181, 2009.

[87] M. Eybpoosh, I. Dikmen, and M. Talat Birgonul, "Identification of risk paths in international construction projects using structural equation modeling," J. Constr. Eng. Manag., vol. 137, no. 12, pp. 1164-1175, 2011.

[88] P. Rezakhani, "Fuzzy MCDM model for risk factor selection in construction projects," Eng. J., vol. 16, no. 5, pp. 79-93, 2012.

[89] I. Ismail, A. H. Memon, and I. A. Rahman, "Expert opinion on risk level for factors affecting time and cost overrun along the project lifecycle in Malaysian construction projects," Int. J. Constr. Technol. Manag., vol. 1, no. 2, p. 2289, 2013.

[90] Y.-C. Kuo and S.-T. Lu, "Using fuzzy multiple criteria decision making approach to enhance risk assessment for metropolitan construction projects," Int. J. Proj. Manag., vol. 31, no. 4, pp. 602-614, 2013.

[91] G. R. Krishnan and M. A. Johny, "Assessment of risk factors in construction project using PI method," Int. Res. J. Eng. Technol., vol. 3, no. 9, pp. 767-770, 2016.

[92] H. Zhi, "Risk management for overseas construction projects," Int. J. Proj. Manag., vol. 13, no. 4, pp. 231-237, 1995.

[93] S. H. Han and J. E. Diekmann, "Approaches for making risk-based go/no-go decision for international projects," J. Constr. Eng. Manag., vol. 127, no. 4, pp. 300-308, 2001.

[94] C. S. Goh and H. Abdul-Rahman, "The identification and management of major risks in the Malaysian construction industry," J. Constr. Dev. Ctries., vol. 18, no. 1, p. 19, 2013.

[95] A. Altoryman, Identification and assessment of risk factors affecting construction projects in the Gulf region : Kuwait and Bahrain, 2014.

[96] L. G. Tipili and I. Yakubu, "Identification and assessment of key risk factors affecting public construction projects in Nigeria: Stakeholders perspectives," J. Eng. Adv. Technol. Stud., vol. 4, no. 2, pp. 20-32, 2016.

[97] I. Mahamid, A. Bruland, and N. Dmaidi, "Causes of delay in road construction projects," J. Manag. Eng., vol. 28, no. 3, pp. 300-310, 2011.

[98] F. Al-Sharif, Financial model for private finance initiative projects applied to school buildings, 2007.

[99] N. A. A. Karim, I. A. Rahman, A. H. Memon, A. A. A. Azis, and N. Jamil, "Significant risk management in construction projects: contractor's perception,” 2012.

[100] F. Nasirzadeh, A. Afshar, M. Khanzadi, and S. Howick, "Integrating system dynamics and fuzzy logic modelling for construction risk management," Constr. Manag. Econ., vol. 26, no. 11, pp. 1197-1212, 2008.

[101] M. A. Akhund, A. R. Khoso, A. A. Pathan, H. U. Imad, and F. Siddiqui, "Risk Attributes, Influencing the Time and Cost Overrun in Joint Venture Construction Projects of Pakistan," Eng. Technol. Appl. Sci. Res., vol. 8, no. 4, pp. 3260-3264, 2018. 
[102] S. Mubin and G. Mubin, "Risk analysis for construction and operation of gas pipeline projects in Pakistan," Pakistan J. Eng. Appl. Sci., vol. 2, 2016.

[103] F. Y. Y. Ling and V. T. P. Hoang, "Political, economic, and legal risks faced in international projects: Case study of Vietnam," J. Prof. issues Eng. Educ. Pract., vol. 136, no. 3, pp. 156-164, 2009.

[104] A. R. Ibrahim, M. S. Abdel, and A. Mohammed, "Risk analysis for construction contractors in Egypt and Yemen," J. Eng. Comput. Sci., vol. 8, no. 2, pp. 109-122, 2016.

[105] L. M. Sastoque, C. A. Arboleda, and J. L. Ponz, "A proposal for risk allocation in social infrastructure projects applying PPP in Colombia," Procedia Eng., vol. 145, pp. 1354-1361, 2016.

[106] S.-T. Lu, S.-H. Yu, and D.-S. Chang, "Using fuzzy multiple criteria decision-making approach for assessing the risk of railway reconstruction project in Taiwan," Sci. World J., vol. 2014, 2014.

[107] N. Van Thuyet and S. O. Ogunlana, "Risk management in oil and gas construction projects in Vietnam," Int. J. energy Sect. Manag., vol. 1, no. 2, pp. 175-194, 2007.

[108] R. M. Choudhry and K. Iqbal, "Identification of risk management system in construction industry in Pakistan," J. Manag. Eng., vol. 29, no. 1, pp. 42-49, 2012.

[109] S. M. E. Sepasgozar, M. A. Razkenari, and K. Barati, "The importance of new technology for delay mitigation in construction projects," Am. J. Civ. Eng. Archit., vol. 3, no. 1, pp. 15-20, 2015.

[110] J. Zayed, T., Amer, M., and Pan, "Assessing risk and uncertainty inherent in Chinese highway projects using AHP,” Int. J. Proj. Manag., vol. 26, no. 4, pp. 408-419, 2008.

[111] V. S. Steffey, R. W., and Anantatmula, "International projects pro- posal analysis: Risk assessment using radial maps," Proj. Manag. J., vol. 42, no. 3, pp. 62-74, 2011.

[112] M. P. Koirala, Infrastructure Construction Risks Identification, Analysis and Response, 2018.

[113] G. A. Niazi and N. Painting, "Significant factors causing cost overruns in the construction industry in Afghanistan," Procedia Eng., vol. 182, pp. 510-517, 2017.

[114] A. Al Khattab, J. Anchor, and E. Davies, "Managerial perceptions of political risk in international projects," Int. J. Proj. Manag., vol. 25, no. 7, pp. 734-743, 2007.

[115] D. Pelling, A., Maskrey, P., Ruiz, P., Hall, P., Peduzzi, Q.H., Reducing disaster risk: A challenge for development, 2004.

[116] N. Chileshe and A. Boadua Yirenkyi-Fianko, "An evaluation of risk factors impacting construction projects in Ghana," J. Eng. Des. Technol., vol. 10, no. 3, pp. 306-329, 2012.

[117] W. H. Kalayjian, Hidden risks of construction in the third world, 2000.

[118] A. Bu-Qammaz, I. Dikmen, and M. T. Birgonul, "Cultural risk assessment in construction projects," 2006.

[119] C. S. Bruce, "Research students' early experiences of the dissertation literature review," Stud. High. Educ., vol. 19, no. 2, pp. 217-229, 1994.

[120] S. McLeod, Questionnaire retrieved from simply phsychology website, 2018. .

[121] A. Hassan, “Assessment of medical waste disposal methods in Hargeisa Public Hospital - Somaliland," Int. J. Soc. Sci. Humanit. Res., vol. 6, no. 4, pp. 1144-1167, 2018.

[122] D. Jonassen, M. J. Spector, M. Driscoll, M. D. Merrill, J. van Merrienboer, and M. P. Driscoll, "Handbook of research on educational communications and technology: a project of the association for educational communications and technology," 2008.

[123] M. Saunders, P. Lewis, and A. Thornhill, Research methods for business students, 2009.

[124] R. B. Kline, Principles and practice of structural equation modeling, 2015.

[125] J. Gaskin, Normality, 2016. [Online]. Available: http://youtube.com/Gaskination:StatsTools Package.

[126] StatWiki,Outliers,2017.[Online]. Available: http://statwiki.kolobkreations.com/index.php?title=Data_screening.

[127] J. Gaskin, Detecting Outliers, 2011. [Online]. Available: https://www.youtube.com/watch?v=vB0WMD-UlJQ.

[128] F. C. Uzonwanne, "Confirmatory factor analysis revalidation of the perceived leadership communication questionnaire (PLCQ-OR),” African J. Psychol. Study Soc. Issues, vol. 20, no. 2, pp. 77-88, 2017.

[129] B. G. Tabachnick, L. S. Fidell, and J. B. Ullman, Using multivariate statistics, 2007.

[130] J. F. Hair, R. E. Anderson, B. J. Babin, and W. C. Black, Multivariate data analysis, 2010.

[131] M. J. Norusis, SPSS Base 9.0 Applications Guide, 1999.

[132] M. M. Foroudi, The Corporate Identity , Architecture , and Identification Triad : Theoretical Insights, 2015.

[133] J. Pallant, SPSS survival manual: A step-by-step guide to data analysis using SPSS for Windows, 2007. 
[134] D. D. Suhr, Exploratory or confirmatory factor analysis?, 2006.

[135] A. Zainudin, Research methodology for business and social science, 2010.

[136] Z. Harun, P. H. Zaki, M. H. Ismail, and K. W. Awang, "The Confirmatory Factor Analysis (CFA) on GST Compliance Research Model in Malaysia," Imp. J. Interdiscip. Res., vol. 2, no. 4, pp. 758-763, 2016.

[137] D. Jöreskog, K., \& Sörbom, LISREL 8: Structural equation modeling with the SIMPLIS command language, 1993.

[138] N. Ahmad and A. Sabri, "Assessing the unidimensionality, reliability, validity and fitness of influential factors of 8th grades student's mathematics achievement in Malaysia," Int. J. Adv. Res., vol. 1, no. 2, pp. 1-7, 2013.

[139] W. Wan Omar, Developing a model for halal food supply chain implementation, 2017. 